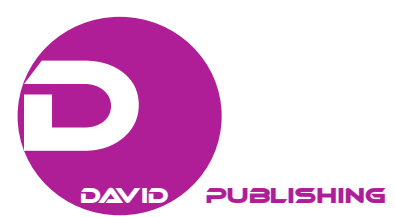

\title{
Human Resource Accounting: Costs and Benefits Analysis
}

\author{
Gürhan Uysal \\ Ondokuz Mayıs University, Samsun, Turkey
}

\begin{abstract}
Human resource accounting is related with intellectual capital in literature. This study adds another dimension for human resource accounting field. It is costs, human resource management related costs. Research topic is intellectual capital and human resource costs in human resource accounting. Research question is that human resource accounting is technic of management accounting. Research methodology is the case study approaches. Main result of study is that human resource costs are recorded in financial accounting and this information might be used by human resource leaders and other executives. Further, human resource of company may be recorded as intellectual capital in balanced sheet. Quantity of record might become total compensation of firms. In conclusion, HR accounting is management accounting technic with its support for information role and decision-making role.
\end{abstract}

Keywords: intellectual capital, costs of human resource management, human resource accounting, management accounting, Henry Mintzberg

\section{Introduction}

Henry Mintzberg explained 10 roles for managers. They are decision-making role and information role. Human resource accounting may support needed information for managers; thus, it enables managers to make human resource related decisions, for example, managers may compare human resource spendings with budget planning of firm, quarterly.

\section{Literature Review: Human Resource Accounting Dimensions}

Human resource accounting records costs and benefits of human resource and intellectual capital as intangible assets. Human resource management departments apply various human resource management practices. Firstly, those practices have a cost itself, such as cost of compensation, cost of staffing, cost of training, cost of industrial relations, and others. Secondly, human resource is recorded as intangible asset in balance sheet. Thirdly, return on investment of human resource may be a matter of financial statement analysis. Human resource management department may compare costs of human resource management practices with benefits of them. Major benefit of human resource might increase individual performance.

Return on investment of human resources is a positive organizational attitude and behaviour. Aim of American human resource management might achieve positive organizational behaviours. Because assumed that positive organizational behaviours have an impact on employee's individual performance. Thus, human resource management is interested with employee performance and human resource management is investment of employees. Major benefit of this investment might become positive organizational attitude and behaviours,

Gürhan Uysal, Ph.D., associate professor, School of Business, Ondokuz Mayıs University, Samsun, Turkey.

Correspondence concerning this article should be addressed to Gürhan Uysal at Ondokuz Mayıs University, School of Business, Kurupelit Campus, 3rd Floor, 55139, Atakum-Samsun, Turkey. 
because return on investment concept includes costs and benefits analyses on firm's investments. This paper studies costs of human resource management practices in firms via human resource accounting. Human resource accounting may be that human resource managers are able to implement costs analysis in human resource.

Human resource accounting may become a technich for management accounting. Because human resource accounting is interested with cost analysis, benefits, budget analysis, and financial recording. Human resource director may track cost and budget limit of human resource through financial recording.

\section{Research Methods}

This paper takes fictive case study for human resource accounting. Below are financial human resource transactions of fictive company (Table 1):

(1) Human resource management department determines personnel budget as 25,000 USD for the term 2016. Board of directors approves this budget limit;

(2) Firm sets a training program in Terma Hotel, Tenessee. Costs of training is 6,000 USD;

(3) Human resource management hires 10 marketing salespersons and two engineers. Costs of staffing process is 2,000 USD;

(4) Total compensation of employees for this company is 20,000 USD. So, cost of compensation is 20,000 USD.

Table 1

Records of Financial Transactions

\begin{tabular}{lll}
\hline No. & Records & Money \\
\hline & Management cost & 25,000 \\
1. & Budget & 25,000 \\
& Cash & 25,000 \\
\hline & Management cost & 6,000 \\
& Training & 6,000 \\
& Cash & 6,000 \\
\hline & Management cost & 2,000 \\
& Staffing & 2,000 \\
& Cash & 2,000 \\
\hline & Management cost & 20,000 \\
& Compensation & 20,000 \\
\hline
\end{tabular}

In the second phase, those records are translated into secondary accounts. This line enables human resource managers to track costs of human resource practices. Thus, human resource manager may implement cost analysis together with budget analyses. Therefore, human resource accounting might become variable of management accounting.

\section{Human Resource Is Intellectual Capital}

Human resource is intellectual capital according to resource-based theory of Barney (1991). Thus, second dimension of human resource accounting is balance sheet with intellectual capital account. Human resource may be recorded for balance sheet through intellectual capital. Variable for recording intellectual capital might 
become total compensation of firm yearly, for example, intern capital firm has 1,000 employees and it has 120,000 USD total compensation plan for the term 2016. So, balance sheet record might become as follows (Table 2).

Table 2

Balanced Sheet of Intern Capital

\begin{tabular}{ll}
\hline Assets & Liabilities \\
\hline Intangible asset & \\
Intellectual capital 120,000 USD & \\
\hline
\end{tabular}

In balance sheet, human resource is recorded as intangible asset. Variable is the total compansation of employees. So, human resource might become management accounting technic.

\section{Research Results}

There are two results in this study. Firstly, human resource is recorded as management costs and intellectual capital in financial accounting. Those records might be used by upper-level managers.

Because human resource of company is accepted as intellectual capital and it is accepted as core competence of firm, according to study of Prahalad and Hamel (1990). Those two concepts may be aligned with resource-based theory of Barney (1991). Core competence is associated with firm's resources and intellectual capital is maybe associated with knowledge concern. Human resources are key resources of a company. Therefore, it may be recorded as intellectual capital in balanced sheet of firm.

\section{Conclusions}

Finally, Henry Mintzberg, professor, defined 10 roles of managers. Two of them are informational role and decision-making role. According to propositions of that study, human resource accounting enables human resource managers and executives to do information and decision-making roles. This paper discusses accounting of human resource management. It is related with cost analysis and budget analysis. Human resource accounting records of costs of human resource management practices. Secondly, human resource accounting shows human resources of company as intangible asset and as intellectual capital in balance sheet.

This paper is standout from other studies with human resource management related costs (Kaya, 2013). Human resource accounting is associated with costs of human resource in this study, in addition to intellectual capital variables.

\section{References}

Barney, J. (1991). Firm resources and sustained competitive advantage. Journal of Management, 17(1), 99-120.

Kaya, U. (2013). HR accounting. Istanbul: Beta.

Prahalad, C. K., \& Hamel, G. (1990). The core competence of the corporation. Harvard Business Review, 68(3), 79-91. 